\title{
RENÚNCIA FISCAL E O DEVER DE POLÍCIA ESTATAL: UM OLHAR SOBRE A INVIABILIDADE DA CONCESSÃO DE BENEFÍCIO FISCAL SOB A LUZ DA INEFICIÊNCIA DO ESTADO
}

\author{
Bruno Pastori Ferreira* \\ Daniel Barile da Silveira*
}

\section{RESUMO}

Tema deste artigo é estudar a necessidade de o Estado exercer seu Poder de Polícia na concessão de benefícios fiscais. O objetivo geral é traçar um norte propedêutico sobre a extrafiscalidade dos tributos e sua correlação com a renúncia de receitas. O objetivo específico é demonstrar que os tributos de natureza extrafiscal, ao serem materializados em benefícios fiscais, impõem ao Estado-renunciante um dever de fiscalização, sob pena de desperdício do dinheiro público. Justifica este artigo, pois os Estados-federados ao conceder benefícios fiscais, deixam de arrecadar, impactando seus orçamentos-financeiros. Será utilizado procedimento bibliográfico e documental, método dedutivo e abordagem qualitativa.

PALAVRAS CHAVES: Tributos; Extrafiscalidade; Renúncia de Receita; Benefícios Fiscais; Poder de Polícia.

\section{FISCAL RESIGNATION AND STATE POLICE DUTY: A VIEW ON THE INVIABILITY OF THE FISCAL BENEFIT CONCESSION UNDER INEFFICIENCY OF THE STATE}

\begin{abstract}
Theme of this article is to study the need for the State to exercise its Police Power in granting tax benefits. General objective is to draw a propaedeutic guideline on the extrafiscality of tribute and their correlation with revenue waiver. Specific objective is to demonstrate that the extrafiscal tribute, when materialized in tax benefits, impose a duty of inspection on the Renouncing-State, under penalty of wasting public money. Justifies the wording of article, since the federal states, when granting tax benefits, stop collecting, impacting their financial budgets. Bibliographic and documentary procedure, deductive method and qualitative approach will be used.
\end{abstract}

KEYWORDS: Tribute; Extrafiscality; Revenue Waiver; Tax benefits; Police power.

\footnotetext{
"Registrador Civil das Pessoas Naturais da Comarca de Canápolis-MG. Professor do Curso de Graduação em Direito do Centro Universitário de Goiatuba-GO. Mestrando em Direito pelo Programa de Pós-graduação Stricto Sensu da Universidade de Marília/SP -UNIMAR. Pós-graduado em Direito Administrativo e em Direito Notarial e Registral. *E-mail: bruno.pastori@ hotmail.com

"Pós-doutor em Democracia e Direitos Humanos pela Universidade de Coimbra, Portugal (Ius Gentium Conimbrigae). Doutor e Mestre em Direito pelo Programa de Pós-Graduação da Faculdade de Direito da Universidade de Brasília (FD-UnB). Professor dos Programas de Doutorado e Mestrado em Direito da Unimar (Universidade de Marília). Professor do Curso de Graduação em Direito do UniToledo (Centro Universitário Toledo - Araçatuba/SP). É advogado empresarial e consultor Compliance, Proteção de Dados e Startups. Fundador do Escritório Barile e Barros Advogados. *E-mail:
} 


\section{INTRODUÇÃO}

Conforme reclames constitucionais colacionados nos artigos 145 a 169, o legislador constituinte primevo estabeleceu e delimitou o regime constitucional tributário-orçamentário pátrio, determinando dentre outras premissas, as atribuições tributárias de cada unidade federativa, o axioma principiológico tributário, as imunidades tributárias, as finanças públicas, as espécies tributárias e a repartição das receitas oriundas da subtração imperativa estatal no patrimônio particular.

O exercício estatal, consistente na diminuição do patrimônio particular, se dá, primordialmente, através da cobrança impositiva de tributo, que depois de exigido e arrecadado torna-se receita pública para o ente-tributante competente.

Essa receita amealhada pelo Estado, deve ser administrada pelo alcaide com tenacidade, probidade, responsabilidade e economicidade, tendo como vetores as ordenanças estabelecidas nos artigos 165 a 169 da Constituição Federal de 1988 (CF/88), bem como nos ditames jungidos no artigo $4^{\circ}$, da Lei de Responsabilidade Fiscal (LRF), sendo poder/dever do gestor público, trazer a lume, uma gestão pública econômica, que equacione o equilíbrio entre receitas e despesas, que estabeleça normas relativas ao controle de custos, que avalie os resultados dos programas financiados com recursos dos orçamentos, que expurgue projetos incompatíveis com a boa governança pública e, que seja estabilizada, distributiva e alocativa.

De mais a mais, incumbe ao Estado presentado pelo seu gestor, nos termos do artigo 170 da $\mathrm{CF} / 88$, promover a "[...] ordem econômica, fundada na valorização do trabalho humano e na livre iniciativa [...]" observando, dentre outros princípios, a soberania estatal, o pleno desenvolvimento da atividade econômica, a garantia da propriedade privada, a livre concorrência e a busca pelo pleno emprego.

As premissas e ordenanças legais alhures, que direcionam e buscam uma boa governabilidade pública, podem/devem ser materializadas através da tributação. Há muito tempo já é ultrapassada a feição do tributo como uma atividade meramente arrecadatória do 
Estado, uma vez que em tempos hodiernos, os tributos têm assumido funções que ultrapassam o mero apite voraz do Estado na expurgação de riquezas da sociedade.

É sabido e tradicional que essas funções do tributo, outrora denominadas de finalidades/objetivos, podem ser divididas em fiscal e extrafiscal. A fiscal consiste na política estatal de jungir receitas de caráter meramente arrecadatório, sem a necessidade vinculativa de uma contraprestação ao contribuinte. Por sua vez, a extrafiscalidade, incide em vetores estatais de caráter precipuamente não arrecadatório, na qual o Estado-tributante busca estimular ou desestimular determinados comportamentos, intervindo, não raras vezes, na ordem econômica. Com isso, a tributação extrafiscal possui dentre outros objetivos não menos respeitáveis, reprimir a inflação, sufragar o desemprego, restaurar a prosperidade, proteger a indústria nacional e promover o desenvolvimento econômico.

Desta forma, os tributos ora assumem finalidades fiscais, cuja incidência remonta a ordinária arrecadação do Estado, outrora ganham roupagem extrafiscal, sendo determinantes para fomentar segmentos da atividade econômica, incentivando ou desincentivando determinadas condutas de atores econômicos.

Esses incentivos ou desincentivos podem ser corporificados através da concessão de benefícios fiscais, que são renúncias primárias de receitas públicas, corolário sendo cogente ao administrador público sopesar os limites estabelecidos na LRF, a qual determina que as finanças públicas devam ser geridas com responsabilidade, evitando, ao grau máximo, a malversação da pecúnia pública.

Diante disso, cogente perquire-se: depois de concedidos os benefícios fiscais, a CF/88 determina que o Poder Público-concedente fiscalize os termos da lei concessiva? Em caso de descumprimento das cláusulas previstas na lei concessiva do benefício, poderia o beneficiário ser compelido, judicialmente ou administrativamente, a devolver ao erário público a pecúnia recebida?

Assim, o objeto de pesquisa do presente artigo é compulsar a necessidade do poder de polícia do Estado-renunciante nas concessões de benefícios fiscais. 
Nessa guisa, o objetivo geral é trazer lições propedêuticas sobre o caráter extrafiscal dos tributos, materializados através de benefícios fiscais e a necessidade de fiscalização do Poder Público-concedente, sob a luz da LRF, dos princípios administrativos que regem a governança pública, coligindo, em determinados casos, pela inviabilidade da concessão de benesses fiscais ante a ineficiência vigilante do Estado-renunciante.

O objetivo específico é demonstrar, ao menos perfunctoriamente, que os tributos de natureza e função extrafiscal, ao serem materializados através de leis concessiva de benefícios fiscais, impõe ao Estado o dever de fiscalização quanto ao destino escorreito dos escopos legiferantes, ou seja, faz-se forçoso que o Estado-renunciante policie se o órgão beneficiário cumpriu ou está cumprindo com as premissas estabelecidas na lei concessiva, sob pena de desperdício do dinheiro público.

Justifica-se a lavra deste artigo, pois a cada ano vindouro, ventilam-se notícias que bilhões de reais serão concedidos em benefícios fiscais pelas pessoas políticas, impactando seus orçamentos-financeiros, podendo causar um enorme desfalque no erário público, caso sejam concedidos de modo indevido.

A título de peça informativa, tendo como paradigma à União, conforme notícia veiculada pelo Portal G1, informação extraída do Ministério da Fazenda, este ente, prevê conceder, no ano de 2019, $\mathrm{R} \$ 376,198$ bilhões de reais em benefícios fiscais.

Apenas no ano pretérito, de acordo com a mesma agência de notícias, estimou-se a concessão de $\mathrm{R} \$ 376,326$ bilhões de reais, fato que, no ano de 2017 , a concessão oscilou para menor, malgrado surtindo pouca diferença, pois a outorga girou em torno de $\mathrm{R} \$ 354,714$ bilhões de reais. Realizando uma média aritmética entre os anos de 2010 a 2018, apenas à União, renunciou o montante de aproximadamente $\mathrm{R} \$ 303,827$ bilhões de reais.

Salta aos olhos as cifras bilionárias na concessão de benesses fiscais pela gestão pública, sendo imprescindível que o Estado-renunciante sopese e fiscalize se as condições e premissas estabelecidas na lei fiscal concessiva estão sendo cumpridas a rigor pelos beneficiários. 
A metodologia a ser observada será o procedimento bibliográfico, através do método dedutivo e com abordagem qualitativa.

\section{EXTRAFISCALIDADE DOS TRIBUTOS}

Antes de imiscuir sobre a extrafiscalidade dos tributos, impende consignar, em escorço, a natureza conceitual das expressões poder de tributar e poder de isentar, uma vez que esta não está positivada de modo expresso no acervo jurídico pátrio.

Sem embargo, isso não significa assoalhar que o Estado Brasileiro não seja posseiro de tal poder, haja vista que analisando e interpretando sistematicamente o conjunto legiferante e doutrinário tributário-constitucional, infere-se que o Estado é o legítimo detentor tanto do poder de tributar como de isentar.

Contudo, para entendermos o poder de isentar, faz-se forçoso analisar o poder de tributar. Nesse diapasão, segundo Sacha Calmon Nazarro Coêlho (2016, p. 33) o poder de tributar é aquele "[...] exercido pelo Estado por delegação do povo”. Destarte, a prerrogativa do poder de tributar está intimamente ligada ao Estado Brasileiro como um todo, e não às unidades políticas que compõem o sistema federativo.

Sobre essas recaem apenas a competência para tributar, que nada mais é, que a possibilidade de criar tributos, mediante manifestação legislativa, respeitada a repartição tributária insculpida no texto constitucional.

Nesse sentido, Vittorio Cassone estabelece que a competência tributária (2015, p. 71) “[...] é a parcela de poder tributário, que a Constituição dá às pessoas políticas.”, recaindo sobre a União, Estado, Município e o Distrito Federal, o alvedrio de criar tributo, mediante lei. 
Tudo isso está amparo no direcionativo legal estampado no artigo $6^{\circ}$ e ss. do Código Tributário Nacional (CTN) que assim expõem sobre a atribuição constitucional das competências tributárias.

Convêm observar, que apesar da CF/88 outorgar o poder de tributar ao Estado Brasileiro, a redação constitucional, de modo algum, instituiu tributos, haja vista que apenas estabeleceu a regra matriz de repartição de competência tributária, como bem assevera Alexandre de Moraes ao dizer que (2017, p. 909) “[...] a Constituição Federal, em regra, não institui tributos, mas sim estabelece a repartição de competência entre os diversos entes federativos e permite que os instituam com observância ao princípio da reserva legal."

Nesse ínterim, Sylvio Clemente da Motta Filho ventila (2016, p. 1044) “[...] que a Constituição, diretamente, não institui qualquer tributo, mas apenas outorga competência a cada pessoa política (União, Estados, Distrito Federal e Municípios) para que o faça, mediante a edição de ato normativo próprio, dentro dos permissivos constitucionais".

Desta forma, colige-se que o exercício do poder tributar é exercido pelo Estado Brasileiro, que concede parcela desse poder às unidades federativas, no escopo, conforme lição de Luciano Amaro (2017, p. 117) de “'[...] atender aos seus respectivos dispêndios.”.

Cogente mencionar, ainda, que a competência tributária não se confunde com a capacidade tributária e nem com o poder de tributar. Nada obstante serem institutos símeis, possuem características singulares, distintivas uma das outras, que marcam suas originalidades.

Diferentemente da competência tributária e do poder de tributar, a capacidade tributária é a prerrogativa que determinadas pessoas jurídicas de direito público possuem, de cobrar, arrecadar, regulamentar, fiscalizar e lançar tributo, desde já tenha sido criado pelo ente federativo competente, nos termos do artigo $7^{\circ}$ do CTN, que assim determina “[...] a competência tributária é indelegável, salvo atribuição das funções de arrecadar ou fiscalizar tributos, ou de executar leis, serviços, atos ou decisões administrativas em matéria tributária, conferida por uma pessoa jurídica de direito público a outra $[\ldots]$ ”. 
Nesse prumo, Leandro Paulsen (2018, p. 96) afirma que “[...] as funções fiscais (regulamentar, fiscalizar, lançar) são delegáveis, porquanto tal implica tão somente transferência ou compartilhamento da titularidade ativa (posição de credor na relação jurídica tributária) ou apenas de atribuições administrativas (atribuições de fiscalizar e lançar)".

Assim, em linhas gerais, o Estado Federal Brasileiro é o detentor legítimo do poder de tributar, sendo que, as unidades federativas possuem a competência tributária para criar o tributo, sopesando a possiblidade de delegar para pessoas jurídicas de direito público, as funções de regulamentar, fiscalizar e lançar o tributo, denominada de capacidade tributária.

Volvendo-se ao poder de isentar, entende-se que as regras conceituais incidentes sobre o poder de tributar igualmente recaem sobre a prerrogativa de isentar, pois através de um simplório silogismo jurídico, materializado pelo paralelismo das formas, se o Estado Federal Brasileiro detêm o poder de tributar, por consequência lógica possui também o poder de isentar, corolário se os entes federativos possuem competência e capacidade para criação, regulamentação, fiscalização e lançamento de tributo, de igual modo, hão de ter todas essas prerrogativas para isentar.

Assim, o poder de isentar deve ser entendido como a prerrogativa que detêm o Estado Brasileiro de lançar mão de receitas. Por sua vez, a competência para isentar, seguindo a premissa paralela das formas, é o alvedrio que as unidades federativas possuem de outorgar benesses fiscais para determinados setores ou pessoas, renunciando receitas próprias, respeitadas à repartição constitucional.

Com isso, ao menos em tese, a União não poderia conceder a isenção do Imposto sobre a Propriedade de Veículos Automotores (IPVA), que é de competência do Estadomembro, do mesmo modo, o Estado-membro, jamais, poderia conceder uma anistia sobre o Imposto Predial e Territorial Urbano (IPTU), que é de competência municipal e assim de modo sucessivo.

Desta forma, detendo as unidades federativas a competência e a capacidade para isentar, torna-se possível a renúncia de receitas, através da concessão de benefícios. Esses são 
materializados por intermédio da tributação extrafiscal, onde o Estado pode se valer dessas benesses para incentivar ou desincentivar determinados comportamentos econômicos.

Sobre o conceito de extrafiscalidade importante observar à primeira vista, a crítica lavrada por Paulo Caliendo (2017, p. 346), onde assoalha que a messe doutrinária não tem primado pelo tecnicismo conceitual deste instituto, pois existe uma:

[...] confusão conceitual sobre a utilização sem critérios claros em termos tais como: externalidades, efeitos extrafiscais, tributos extrafiscais e princípios atinentes, em um verdadeiro sincretismo teórico, ou seja, com a mistura de temáticas tão diversas como política fiscal, economia pública e direito tributário.

Nada obstante a crítica levantada pelo doutrinador, entendemos que a extrafiscalidade se dá nos termos ventilado por Hugo de Brito Machado Segundo (2017, p. 53), sendo caracterizada:

[...] quando o tributo é utilizado para um fim, ou um propósito, diferente da obtenção de receitas. A entidade não institui e cobra o tributo para financiar seu orçamento, ou o orçamento de "prolongamentos" seus, mas sim para atingir outras finalidades, dirigindo comportamentos, estimulando ou desestimulando condutas etc.

Nesse sentido, Cláudia de Rezende Machado de Araújo (1996, p. 329) preleciona que “[...] os impostos não estão sempre relacionados à despesa estatal; ao contrário, muitas vezes têm como finalidade impor ou coibir comportamentos aos particulares. Neste último caso, ocorre o fenômeno chamado de extrafiscalidade.”.

Ainda, Oksandro Osdival Gonçalves e Marcelo Miranda Ribeiro (2013, p. 79) situam que "[...] de todo o modo, a extrafiscalidade abre uma importante perspectiva de intervenção estatal do Estado na ordem econômica com o poder de incentivar ou desincentivar certas atividades ou setores econômicos.”.

Nada obstante, o Estado apenas poderá ser valer da tributação extrafiscal quando o mercado econômico apresentar falhas, seja por desinformação ou por abuso do poder econômico, ocasião que segundo Oksandro Osdival Gonçalves e Marcelo Miranda Ribeiro (2013, p. 88) " [...] apesar de o mercado ser o melhor local para se obter a eficiência alocativa 
ótima, não raro apresenta falhas. Somente na presença destas deve haver a intervenção estatal, mas ainda assim de forma pontual e específica, a fim de eliminá-las.”.

Assim, a tributação extrafiscal poderá ser utilizada pelo Estado apenas em situações peculiares, singulares e não ordinárias, uma vez que a $\mathrm{CF} / 88$ estabelece a intervenção mínima estatal, devendo o mercado se desenvolver com o seu próprio fluxo, expurgando condutas atentatórias à boa-fé e aos bons costumes, de mais a mais, respeitando os direitos e garantias fundamentais dos cidadãos.

Constatada essa situação ímpar, o Estado terá o alvedrio de adentrar na seara econômica para garantir o seu pleno desenvolvimento socioeconômico, para isso se valendo dos incentivos fiscais.

Esses incentivos fiscais são instrumentos postos à disposição do Estado para intervirem no domínio econômico, estimulando comportamentos e freando determinadas condutas atentatórias ao livre mercado.

Para Oksandro Osdival Gonçalves e Marcelo Miranda Ribeiro esses incentivos (2013, p. 91) " [...] podem assumir roupagens diversas, dentre as quais as isenções, reduções de alíquotas e/ou bases de cálculo, anistia, moratória, remissão, concessão de créditos tributários, diferimento do pagamento de tributos, créditos presumidos, alíquotas zero, entre outros.".

Inclusive, os incentivos fiscais podem assumir estrutura de exonerações, como tido por Aliomar Baleeiro e Misabel Derzi (2018, p. 1340), podem ser exógenas ou endógenas. As exonerações exógenas são aquelas “[...] que não alteram a estrutura interna da norma tributária, [...]" tendo como pressuposto "[...] prévio nascimento da obrigação tributária, extinguindo-a como na remissão, na compensação, na prescrição e na decadência; ou pressupõem mesmo o cumprimento do dever tributário, anulando-lhe os efeitos, como na devolução de tributo pago." Lado outro, as exonerações endógenas, sendo aquelas "[...]que atuam tanto na estrutura da norma tributária como na isenção, na alíquota zero, na base de cálculo presumida.". 
Com isso, a extrafiscalidade se solidifica através da concessão de benefícios fiscais, até porque não existem tributos genuinamente extrafiscais, conforme preleciona André Elali (2007, p. 39) “[...] não há tributo exclusivamente relacionado à função extrafiscal, porque sempre haverá um nível, mesmo que mínimo, de fiscalidade se materializa através de benefícios fiscais.”, assim, não existindo tributos puramente com finalidades extrafiscais.

Contudo, conforme mencionado noutro lugar, quando o Estado concede benefícios fiscais para os mais diversos atores econômicos, através da tributação extrafiscal, automaticamente há a renúncia de receitas, com efeito, existe um impacto econômicofinanceiro no orçamento, que deve ser devidamente analisado pela Administração Pública, ssso porque, existe um claro limitador legal para a concessão de benesses fiscais, colacionado no artigo 14 e ss. da LRF.

Colige-se que, para haver a concessão de qualquer benefício fiscal, por uma das unidades federativas, da qual decorra renúncia de receita, torna-se cogente a estimativa do impacto orçamentário-financeiro no exercício em que deva iniciar sua vigência e nos dois seguintes, pois o que se renúncia não é particular e sim público, pertencente a todos que contribuem tributariamente para o desenvolvimento estatal.

Não se pode olvidar que após a concessão, torna-se imperioso que o beneficiário permaneça a desenvolver suas atividades no local de concessão, sob pena de enriquecimento ilícito do beneficiário, uma vez que lesa toda a malha patrimonial pública.

Nessa sonda, Claudio Carneiro (2018, p. 61) entende que “[...] o administrador público, ainda que amparado por lei, não poderia, livremente, dispor do dinheiro, que é do povo.".

Desta forma, a atuação do Estado na fiscalização da escorreita contrapartida do beneficiário, é de extrema relevância para o trato probo, responsável e legal da res pública.

\section{DA NECESSIDADE DE FISCALIZAÇÃO DAS ENTIDADES RENUNCIANTES}


Kiyoshi Harada (2017, p. 41) prediz que a receita pública "[...] é o ingresso de dinheiro aos cofres do Estado para atendimento de suas finalidades." Desta forma, o Estado necessita da arrecadação de pecúnia para manter erigida a sua estrutura orgânica, bem como para realizar os desideratos constitucionais que lhe foi imposto.

Nesse sentido, Ives Gandra Martins (2013, p. 108) com maestria preconiza que o Estado busca a "[...] obtenção das receitas necessárias à sua existência e da administração de tais recursos na consecução de seus objetivos.".

Para tanto, a própria CF/88 direcionou o administrador público estatal para uma boa governança pública, preconizando diretrizes financeiras estatais, aptas a serem formuladas por intermédio de orçamentos públicos.

Entende-se por o orçamento público, nos dizeres de Kiyoshi Harada (2017, p. 73) “[...] como uma peça que contém a aprovação prévia da despesa e da receita para um período determinado."

Nada obstante, o próprio doutrinador alhures ressalta que esse conceito se insere em sua mais concepção clássica, uma vez que, hodiernamente, houve-se uma mutação conceitual de orçamento publico, ganhando os mais diversos contornos, dentre os quais o paradigma fiscalizatório.

Nessa escora, ensina Edilberto Carlos Pontes Lima (2015, p. 105)

[...] O orçamento surgiu como um instrumento de controle do parlamento ao rei. Essa é uma de suas principais finalidades. Além de instrumento de planejamento e de transparência, ele é essencialmente um meio de o Poder Legislativo controlar a administração pública, pois só se destinam recursos após aprovação legislativa [...]

Assim, o orçamento público, além de ser o demonstrativo de receita e despesa do Estado, também é o instrumento apto, posto à disposição da sociedade e os demais meios de controle, para fiscalizar o emprego escorreito dos recursos públicos. 
Desta forma, a atuação econômico-financeira do Estado fica supervisionada pela sociedade, podendo sopesar onde, quando, quanto e como o dinheiro público arrecadado foi utilizado pelo gestor público.

É por intermédio do orçamento público que o Estado estima de modo anual até quatrienal o fluxo de receita e despesa, tendo durante esse hiato, o alvedrio, a depender da estimativa de entrada e saída de dinheiro, a prerrogativa de estabelecer as melhores e mais convenientes políticas públicas.

Destarte, considerando essas lições alhures, subentende-se que o gestor público deve elaborar o orçamento público, com fim de carrear a maior eficiência alocativa dos recursos públicos.

Com esse feeling, o alcaide deve se preocupar com tenacidade na concessão de benefícios de fiscais, pois pode caracterizar um abalo nas finanças públicas, podendo ocasionar um desequilíbrio nas contas públicas.

Ao conceder determinado benefício, as unidades federativas deixam de amealhar receitas, renunciando a fonte primária de pecúnia, com isso, torna-se imprescindível a fiscalização do ente-concedente, no sentido de averiguar se os benefícios físcais estão surgindo o efeito almejado e se a contrapartida exigida dos beneficiários está sendo devidamente cumprida.

O dever de fiscalização estatal sobre as diretrizes e bases do planejamento do desenvolvimento nacional equilibrado é ordenança constitucional plasmada no artigo 70 da $\mathrm{CF} / 88$.

Nesse seguimento, Maria de Fátima Ribeiro e Jonathan Barros Vita (2015, p. 177) expõem que "[...] de igual forma, prescreve que como agente regulador da atividade econômica, o Estado exercerá, na forma da lei, as funções de fiscalizador, incentivo e planejamento (art. $\left.174, \S 1^{\circ}\right)$.”. 
Assim, a CF/88 deixa clarividente que o Estado, através do controle externo e interno, deve fiscalizar a renúncia de receitas, quanto aos seus aspectos de legalidade, legitimidade e economicidade.

O Estado constatando que o beneficiário de determinada benesse fiscal, não está cumprindo com a contrapartida estabelecida na lei concessiva, por óbvio, que torna a concessão flagrantemente ilegal, sendo imperiosa a sua retirada do mundo jurídico, através do princípio da autotutela.

Sabe-se que atos eivados de ilegalidade, não coadunam com os preceitos de moralidade, legalidade, eficiência, economicidade, probidade, legitimidade, devendo ser expurgados da seara jurídico. A Administração Pública deve aplicar a lei de ofício, desde que esteja em conformidade com os regramentos e ditames do ordenamento jurídico.

Cita-se, por exemplo, casos relacionados à Lei n. ${ }^{\circ}$ 8.313/91, vulgarmente conhecida como Lei Rouanet, onde existem notícias que a concessão de benefícios fiscais tem sido extremamente deturpada, uma vez que se considera fomento à cultura, filmes e demais produções dessa estirpe, que frontalmente desrespeitam os valores e os ideais de uma sociedade calcada em preceitos morais enaltecedores à boa fama, aos bons costumes e aos comportamentos escorreitos que direcionam uma sociedade fundada em preceitos que garantem decência e o convívio civilizado.

De acordo com o portal Salic, provedor administrado pelo Ministério da Cultura, destinado para garantir a transparência de dados relacionados à renúncia fiscal advindos da Lei Rouanet, testifica que no ano de 2018, a entidade federal abonou $\mathrm{R} \$ 1.427 .752 .087,00$ (um bilhão, quatrocentos vinte sete milhões, setecentos cinquenta dois mil e oitenta sete reais).

Não menos importante, no ano de 2017 houve-se a renúncia fiscal de R \$1.357.912.134,00 (um bilhão, trezentos cinquenta sete milhões, novecentos doze mil e cento trinta quatro reais). Fazendo uma média aritmética dos últimos 14 (quatorze) anos, a União renunciou $\mathrm{R} \$ 15.453 .746 .054,00$ (quinze bilhões, quatrocentos cinquenta três milhões, setecentos quarenta seis mil e cinquenta quatro reais). 
Nota-se que os valores alhures, tangenciam apenas a renúncia fiscal relacionada à Lei Rouanet, fato que os entes federativos concedem inúmeros outros incentivos fiscais que não decorrem exclusivamente do fomento à cultura.

De mais a mais, apesar de não ser objeto do presente trabalho, convêm consignar que o fomento a cultura, derivado da Lei Rouanet, fica regionalizado no Sul e Sudeste do país, não jungindo equidade para as regiões Norte, Nordeste e Centro Oeste.

Nessa trilha, com espeque nos dados ventilados pelo portal Salic, nos últimos anos, as entidades que mais se beneficiaram com o inventivo governamental à cultura, estão sediadas nas regiões Sul e Sudeste do país. Ao analisar a tabela de fluxos de benefícios fiscais outorgados pela Administração Pública Direta Federal, constata-se que as entidades das regiões suprajacentes receberam valores superiores as das regiões Norte, Nordeste e Centro Oeste, o que nos parece, prima facie, inconsistente, pois a demanda desenvolvimentista do país deve permear as regiões que mais padecem de toda sorte de fomento, inclusive à cultura.

Volvendo ao estudo do presente artigo, conforme preleciona o artigo 37 da CF/88, a Administração Pública deve pautar sua atuação no princípio da legalidade, em havendo a constatação de qualquer ilegalidade, o Poder Judiciário deve/pode ser acionado para suprimir $\mathrm{o}$ ato vicioso.

Sendo assim, caso haja a constatação de qualquer ilegalidade na concessão de benefícios fiscais, não há nenhuma objeção da atuação do Poder Judiciário para cancelar o ato concessivo, por desrespeito à lei.

De mais a mais, caso o beneficiário não comprove a destinação correta prevista na lei concessiva, deverá ser compelido a devolver a pecúnia recebida a título de benefício fiscal, sob de enriquecimento ilícito e malversação de recursos públicos.

Nesse meandro, os Tribunais de Contas exercem papel fundamental, pois a eles incumbem o mister de auxiliar o Poder Legislativo no controle externo das finanças pública, conforme dicção do artigo 70 da CF/88. 
Indo mais além, se valendo dos preceitos constitucionais e infraconstitucionais jungidos na LRF, Rosane Heineck Schmitt (2015, p. 106) assoalha que os Tribunais de Contas, no exercício de seu poder fiscalizatório, têm-se transformados:

[...] em seus legítimos guardiões e corresponsáveis da implantação, determinada na lei, de reformulação do agir da administração pública, para modernizá-la e adequá-la às exigências dos novos tempos, através do planejamento de sua ação, objetivando a legitimidade, eficiência e eficácia da gestão da res publica, reivindicação de há muito reclamada pela sociedade brasileira.

Assim é de cognição solar que os Tribunais de Contas exercem papel fundamental na fiscalização das contas públicas, inclusive sendo perfeitamente possível atribuir a essas Cortes o compulsar da límpida destinação dos benefícios fiscais, materializados, muita das vezes, através de renúncias fiscais.

Nesse prumo, André Ramos Tavares (2018, p.1007) advoga que "[...] os tribunais de contas, como controladores, são necessariamente órgãos direcionados à verificação da compatibilidade entre certa atividade e as regras às quais há de se submeter essa atividade.”.

Com isso, nos parece razoável, através de uma intepretação teleológica do texto constitucional alhures, que o TCU ao ser legitimado para exercício da fiscalização contábil, financeira, orçamentária, operacional e patrimonial, quanto à legalidade, legitimidade e economicidade, está imbuído de zelar pela aplicação condigna das outorgas de benesses fiscais.

Inclusive, às Cortes de Contas, em especial o Tribunal de Contas da União (TCU), tamanha sua importância para a engrenagem do sistema fiscalizatório pátrio, no que tange ao destino escorreito da pecúnia pública, possui, dentre outros encargos, o de julgar as contas dos administradores, fiscalizar a aplicação dos repasses financeiros, assinalar prazo para o cumprimento de providências, inclusive podendo sustar atos, conforme preleciona o artigo 71 e ss. da CF/88.

Destarte, assevera o texto constitucional que o TCU possui legitimidade para o julgamento das contas dos alcaides, para exercer o poder de fiscalização conquanto ao repasse de quaisquer recursos públicos, a prerrogativa de assinalar prazo para o cumprimento exato da 
lei, em casos irregularidades, inclusive podendo sustar atos, desde que respeitadas às premissas condicionatórias previstas no assoalhar constitucional, reforçando o entendimento de que à Corte de Contas da União deve/pode fiscalizar a destinação das renúncias fiscais.

Em decorrência do princípio da simetria, entende-se que as atribuições conferidas ao Tribunal de Contas da União, são extensivas às Cortes de Contas Estaduais e Municipais, desde que respeitadas e adequadas às circunstâncias peculiares de cada unidade federativa, como por exemplo, a composição do Poder Legiferante.

Nessa guisa, sopesando os Tribunais de Contas que o escopo estampado em determinada manifestação legiferante concessiva de benefício fiscal, foi desvirtuado, malversado, corrompido etc, nos parece, constitucional e perfeitamente viável, sua atuação, possuindo legitimidade para aplicar sanções e correções ante as condutas que contenham desvio de finalidade.

Conforme denota Luiz Henrique Lima (2018, p. 85) as Cortes de Contas possuem função sancionatória e corretiva, sendo que aquela possibilita, dentre outras medidas, “[...] multa por irregularidade, por descumprimento de determinação ou por obstrução a auditoria ou inspeção; multa por infrações administrativas às leis de finanças públicas; e decretação da indisponibilidade de bens" e esta “[...] emissão de determinações e recomendações aos órgãos jurisdicionados; fixação de prazo para adoção de providências; sustação de atos irregulares; e adoção de medidas cautelares.”.

É inolvidável, conforme preleciona o artigo $71, \S 3^{\circ}$, da $\mathrm{CF} / 88$ que as decisões dos Tribunais de Contas “[...] de que resulte imputação de débito ou multa terão eficácia de título executivo.".

Nesse sentido, exercendo seu poder fiscalizatório, verbi gratia, poderia às Cortes de Contas, frente ao desrespeito quanto ao destino correto dos recursos advindos da lei concessiva de benefício fiscal, imputar ao beneficiado uma multa administrativa, decorrente de sua função sancionatória, bem como assinalar prazo para o beneficiário cumpra os requisitos colacionados na lei concessiva etc, ambos tendo eficácia de títulos executivos. 
Malgrado com supedâneo nas lições de Edson Simões (2014, p.49) essas decisões executivas das Cortes de Contas demandam ser “[...] efetivada(s) junto ao Poder Judiciário, na forma da lei."

Importante observar que a fiscalização não recairia apenas na figura do beneficiário, conforme ensina Moacir Marques da Silva (2018, p. 128), mas também “[...] preferentemente, mediante auditorias, inspeções ou acompanhamentos nos órgãos supervisores, bancos operadores e fundos que tenham atribuição administrativa de conceder, gerenciar ou utilizar os recursos $[\ldots] ”$.

Além do mais, não se pode esquecer, que o tema recai sobre a tutela jurídica de direitos amplos, sendo perfeitamente possível a atuação do Ministério Público, das ouvidorias e dos observatórios da sociedade civil.

É sabido que o Estado Federal Brasileiro possui contornos continentais, seja em seu aspecto territorial, econômico, populacional, entre outros, com isso, a incidência de fiscalização resta prejudicada ante a imensidão de recursos, atos e demais atos que são praticados no país.

\section{CONSIDERAÇÕES FINAIS}

Como visto, a atuação do gestor público deve ser pautada na Lei, respeitando sempre a fonte legislativa, expurgando qualquer conduta pessoal na governança pública retirando assim, o caráter de pessoalidade das decisões públicas.

Ainda mais, se as deliberações versarem sobre recursos públicos, pois neste caso, deve-se haver uma cautela do alcaide nas movimentações políticas, no escopo de direcionar a aplicação da pecúnia pública sob a luz dos anseios da sociedade.

Para isso, a LRF traz consigo repreensões e advertência de boa governabilidade pública, orientado ao gestor jungir uma administração com transparência, responsabilidade, 
economicidade, probidade, publicidade e respeito aos ditames colacionados nas manifestações lefigerantes.

O Estado poderá se valer da tributação com a finalidade extrafiscal para conceder uma otimizada governabilidade pública, buscando cumprir os desideratos jungidos na CF/88, LRF e demais disposições orçamentárias, através da concessão de benefícios de fisscais.

Nada obstante, a outorga de benesse fiscal exige-se do beneficiário uma contrapartida que deve ser prevista na lei concessiva, consistente na realização de determinados comportamentos que busquem a efetiva melhoria do desenvolvimento socioeconômico do país, uma vez que o Estado ao conceder determinado benefício fiscal está automaticamente, de forma umbilical, renunciando receita. Com isso, emerge-se a imperiosidade do beneficiário promover o interesse público primário e secundário, não se escusando das obrigações previstas na lei concessiva.

Por se tratar de renúncia de receitas, a própria $\mathrm{CF} / 88$ determina que o Estado exerça seu poder fiscalizatório e sancionatório, sopesando os aspectos de legalidade, legitimidade e economicidade das concessões fiscais.

Defende-se, com esteio nos princípios regentes da Administração Pública, dentre os quais autotutela e legalidade, que se que o beneficiário de determinada benesse fiscal, não esteja cumprindo com a contrapartida outrora estabelecida, deve o Poder Judiciário ser chamado a reestabelecer o equilíbrio e os parâmetros estabelecidos na lei concessiva.

Pois, atos viciosos, de modo algum, devem permear o mundo jurídico, pois geram externalidades negativas, tais como má governança pública, desperdício de dinheiro público, inobservância das manifestações da representatividade popular etc.

De mais a mais, entende-se que o beneficiário deve comprovar a escorreita destinação prevista na lei concessiva. Caso não logre êxito, deve ser compelido a devolver a pecúnia recebida em forma de benefício fiscal, sob de enriquecimento ilícito e malversação de recursos públicos. 
Inolvidável que o Estado, presentado por cada unidade federativa, apenas se valerá da tributação extrafiscal para garantir os desideratos da livre concorrência, buscando intervir minimamente na seara econômica, até porque, a CF/88 adotou-se como sistema econômico o regime capitalista, que traz consigo o livre mercado, a livre iniciativa e a ínfima intervenção estatal.

Em hipótese alguma, o Estado poderá se escusar de realizar os procedimentos fiscalizatórios conquanto a destinação dos benefícios fiscais concedidos, ainda que sob o palio dos argumentos de ausência de entidades de policiamento e agigantamento estatal, pois res pública deve ser tratada com prioridade.

Parece-nos razoável que política de incentivo fiscal, sendo uma das modalidades de renúncia de receita, é um bom caminho para fluidez do mercado, para o desenvolvimento econômico equilibrado, organizado e sustentável, desembocando em uma eficiência alocativa, distributiva e produtiva, marchando avante para produção de renda, emprego, estabilidade e segurança.

Portanto, sugere-se que seja intensificada a fiscalização pelas Cortes de Contas dos benefícios concedidos, haja vista a determinação constitucional estabelecendo sua atribuição de polícia conquanto aos repasses advindos de renúncia fiscal.

Infelizmente, determinados atores econômicos apenas cumprem com lei, mediante a fiscalização estatal Algo incompreensível, pois apesar do ser humano nascer corruptível, morto em seus próprios delitos, deveria permear sobre si um senso mínimo de dever com a humanidade como um todo, lastreando e aspergindo honestidade, probidade, lealdade etc.

\section{REFERÊNCIAS}

AMARO, Luciano. Direito tributário brasileiro. 22. ed. São Paulo: Saraiva, 2017. 
ARAÚJO. Cláudia de Rezende Machado de. Extrafiscalidade... Revista de Informação Legislativa, Brasília, out., dez. 1996, no 132, out/dez, p. 329 a 334.

BALEEIRO, Aliomar; DERZI. Misabel Abreu Machado. Direito tributário brasileiro. 14. ed., rev. atual. e ampl. Rio de Janeiro: Forense, 2018.

BRASIL. [Código Tributário Nacional]. Lei $n^{0}$ 5.172, de 25 de outubro de 1966. Dispõe sobre o Sistema Tributário Nacional e institui normas gerais de direito tributário aplicáveis à União, Estados e Municípios. Brasília, DF: Presidência da República, [2019]. Disponível em: http://www.planalto.gov.br/ccivil_03/LEIS/L5172.htm. Acesso: 01 fev. 2019.

BRASIL. [Constituição (1988)]. Constituição da República Federativa do Brasil. Brasília, DF: Presidência da República, [2019]. Disponível em: http://www.planalto.gov.br/ccivil_03/Constituicao/Constituicao.htm. Acesso: 17 jan. 2019.

BRASIL. [Lei Roua]. Lei n. ${ }^{\mathbf{8}}$ 8.313, de 23 de dezembro de 1991. Restabelece princípios da Lei $\mathrm{n}^{\circ}$ 7.505, de 2 de julho de 1986, institui o Programa Nacional de Apoio à Cultura (Pronac) e dá outras providências. Brasília, DF: Presidência da República, [2019]. Disponível em: http://www.planalto.gov.br/ccivil_03/LEIS/L8313cons.htm. Acesso: 03 fev. 2019.

BRASIL. [Lei de Responsabilidade Fiscal]. Lei Complementar $\mathbf{n}^{0} 101$, de 04 de maio de 2000. Estabelece normas de finanças públicas voltadas para a responsabilidade na gestão fiscal e dá outras providências. Brasília, DF: Presidência da República, [2019]. Disponível em: http://www.planalto.gov.br/ccivil_03/LEIS/LCP/Lcp101.htm. Acesso: 01 fev. 2019.

CASSONE, Vittorio. Direito tributário. Prefácio de Ives Gandra da Silva Martins 27. ed. São Paulo: Atlas, 2017.

CALIENDO, Paulo. Curso de direito tributário. São Paulo: Saraiva, 2017.

CARNEIRO, Claudio. Curso de direito tributário e financeiro. 7. ed. São Paulo : Saraiva Educação, 2018.

COÊLHO, Sacha Calmon Navarro. Curso de direito tributário brasileiro. $15^{\mathrm{a}}$ ed. rev. e atual. Rio de Janeiro: Forense, 2016.

ELALI. André. Incentivos Fiscais, Neutralidade da Tributação e Desenvolvimento Econômico: A questão da Redução das Desigualdades Regionais e Sociais., in Incentivos Fiscais: questões pontuais nas esferas Federal, Estadual e Municipal (coord. Ives Gandra da Silva Martins e Marcelo M. Peixoto), MP Editora, SP, 2007.

GONÇALVES, Oksandro Osdival; RIBEIRO, Marcelo Miranda. Incentivos Fiscais: Uma perspectiva da Análise Econômica do Direito. Revista EALR, jan., jun. 2013, v. 4, nº 1, p. 79-102.

GOVERNO FEDERAL. Portal Salic. Transparência dos atos do Ministério da Cultura relacionados aos mecanismos de renúncia fiscal. Disponível em: http://sistemas.cultura.gov.br/comparar/salicnet/salicnet.php. Acesso em: 10 abr. 2019.

GOVERnO FEDERAL. Portal Salic. Projetos aprovados pelo Ministério da Cultura. Disponível

em:

http://sistemas.cultura.gov.br/comparar/container_Proposta/container_Proposta.php. Acesso em: 10 abr. 2019

GOVERNO FEDERAL. Portal Salic. Maiores projetos de incentivo fiscal. Disponível em: http://sistemas.cultura.gov.br/comparar/grid_Maiores_Projetos_IncentivoFiscal/grid_Maiores _Projetos_IncentivoFiscal.php. Acesso em: 10 abr. 2019

HARADA, Kiyoshi. Direito financeiro e tributário. 26. ed. rev., atual. e ampl. São Paulo: Atlas, 2017.

LIMA, Edilberto Carlos Pontes. Curso de finanças públicas: uma abordagem contemporânea. São Paulo: Atlas, 2015. 
LIMA, Luiz Henrique. Controle externo: teoria e jurisprudência para os tribunais de contas. 07. ed. rev. e atual. Rio de Janeiro : Forense; São Paulo : MÉTODO, 2018.

MORAES, Alexandre de. Direito constitucional. 33. ed. rev. e atual. até a EC no 95, de 15 de dezembro de 2016. São Paulo: Atlas, 2017.

MOTTA FILHO, Sylvio Clemente da. Direito constitucional: teoria, jurisprudência e questões. Sylvio Clemente da Motta Filho. 26. ed. rev., atual. e ampl. Rio de Janeiro: Forense; São Paulo: Método, 2016.

MACHADO SEGUNDO, Hugo de Brito. Manual de Direito Tributário. 9. ed. ref. ampl. e atual. São Paulo: Atlas, 2017.

MARQUES, Euvaldo. Finanças públicas. São Paulo: Saraiva, 2015.

MARTELLO, Alexandro. Governo estima conceder $\mathbf{R} \$ \mathbf{3 7 6}$ bi em incentivos fiscais em 2019. Portal G1, Brasília, 20 set. 2018. Disponível em: https://g1.globo.com/economia/noticia/2018/09/20/governo-estima-conceder-r-376-bi-emincentivos-fiscais-em-2019.ghtml. Acesso em: 02 fev. 2019.

MARTINS, Ives Gandra da Silva. Tratado de direito financeiro, volume 1. São Paulo: Saraiva, 2013.

PAULSEN, Leandro. Curso de direito tributário completo. 9. ed. São Paulo: Saraiva Educação, 2018.

RIBEIRO, Maria de Fátima. VITTA. Jonathan Barros. Considerações sobre a política fiscal e os caminhos da extrafiscalidade. In: XXIV Encontro Nacional do Conpedi - UFS, Direito tributário e financeiro [Recurso eletrônico on-line] organização CONPEDI/UFS; Coordenadores: Antônio Carlos Diniz Murta, Hugo de Brito Machado Segundo, Raymundo Juliano Feitosa. Florianópolis: CONPEDI, 2015. Disponível em: https://www.conpedi.org.br/publicacoes/c178h0tg/z6ga0z97/cfK7hgdns7RyAZ16.pdf. Acesso em 03 de fev. 2019.

SCHMITT, Rosane Heineck. Tribunais de contas no Brasil e controle de constitucionalidade; atualizado por Leonardo Tricot Saldanha. São Paulo: Atlas, 2015.

SILVA, Moacir Marques da. Controle externo das contas públicas : o processo nos Tribunais de Contas do Brasil. São Paulo: Atlas, 2014.

SIMÕES, Edson. Tribunais de contas: controle externo das contas públicas. São Paulo: Saraiva, 2014.

TAVARES, André Ramos. Curso de direito constitucional. 16. ed. São Paulo: Saraiva Educação, 2018. 